\title{
Divergence of compost extract and bio-organic manure effects on lucerne plant and soil
}

\author{
Haiyan Ren ${ }^{\text {Corresp., }}{ }^{1}$, Jian Hu ${ }^{1}$, Yifei Hu ${ }^{1}$, Gaowen Yang ${ }^{1}$ \\ ${ }^{1}$ College of Agro-grassland Science, Nanjing Agricultural University, Nanjing, China \\ Corresponding Author: Haiyan Ren \\ Email address: hren@njau.edu.cn
}

Aim: Application of organic materials into agricultural systems enhances plant growth, yields, and improves soil fertility and structure. This study aimed to examine the effects of "compost extract (CE)", a soil conditioner, and bio-organic manure (BOM) on the growth of lucerne ( Medicago sativa ), and compare the efficiency between BOM (including numbers of microorganisms) and CE (including no added microorganisms).

Method: A greenhouse experiment was conducted with four soil amendment treatments (control, BOM, CE and CEBOM), and was arranged in a completely randomized design with 10 replicates for each treatment. Plant biomass, nutritive value and rhizobia efficacy as well as soil characteristics were monitored.

Result: CE rather than BOM application showed a positive effect on plant growth and soil properties when compared with the control. Lucerne nodulation responded equally to CE addition and rhizobium inoculation. CE alone and in combination with BOM significantly increased plant growth and soil microbial activities and improved soil structure. The synergistic effects of CE and BOM indicate that applying CE and BOM together could increase their efficiency, leading to higher economic returns and improved soil health. However, CE alone is more effective for legume growth since nodulation was suppressed by nitrogen input from BOM. CE had a higher efficiency than BOM for enriching soil indigenous microorganisms instead of adding microorganisms and favouring plant nodulation. 
Divergence of compost extract and bio-organic manure effects on lucerne plant and soil

Running title: Compost extract improve lucerne nodulation process

\section{Haiyan Ren*, Jian Hu, Yifei Hu, Gaowen Yang}

College of Agro-grassland Science, Nanjing Agricultural University, Nanjing 210000, China

Postal address: Nanjing Agriculture University, College of Agro-grassland Science, Nanjing

210095, Jiangsu, Peoples R China. Tel: (86) 025-84399736

Corresponding author: Haiyan Ren, *E-mail: hren@njau.edu.cn 


\section{Abstract}

2 Aim: Application of organic materials into agricultural systems enhances plant growth, yields,

3 and improves soil fertility and structure. This study aimed to examine the effects of "compost

4 extract (CE)", a soil conditioner, and bio-organic manure (BOM) on the growth of lucerne

5 (Medicago sativa), and compare the efficiency between BOM (including numbers of

6 microorganisms) and CE (including no added microorganisms).

7 Method: A greenhouse experiment was conducted with four soil amendment treatments (control,

8 BOM, CE and CEBOM), and was arranged in a completely randomized design with 10 replicates

9 for each treatment. Plant biomass, nutritive value and rhizobia efficacy as well as soil

10 characteristics were monitored.

11 Result: CE rather than BOM application showed a positive effect on plant growth and soil

12 properties when compared with the control. Lucerne nodulation responded equally to $\mathrm{CE}$

13 addition and rhizobium inoculation. CE alone and in combination with BOM significantly

14 increased plant growth and soil microbial activities and improved soil structure. The synergistic

15 effects of $\mathrm{CE}$ and $\mathrm{BOM}$ indicate that applying $\mathrm{CE}$ and BOM together could increase their

16 efficiency, leading to higher economic returns and improved soil health. However, CE alone is

17 more effective for legume growth since nodulation was suppressed by nitrogen input from BOM.

18 CE had a higher efficiency than BOM for enriching soil indigenous microorganisms instead of

19 adding microorganisms and favouring plant nodulation.

20 Keywords: compost extract, bio-organic manure, soil amendment, indigenous microorganisms, 
21 nodulation

Introduction

24 Preserving and restoring native grasslands and agricultural production systems by improving 25 soil quality have been common goals worldwide (Henwood 2010). However, long-term inappropriate management and large inputs of chemical fertilizers and pesticides into soils have led to severe soil problems. Commercial soil conditioners or manures are used in agricultural production systems for amending nutrient-deficient soils by providing multiple nutrients (Soumare et al. 2003, Hu and Qi 2013), including, but not limited to, bio-organic manure (BOM), effective microorganisms (EM), and compost extract (CE). However, farmers are sometimes reluctant to use organic fertilizers because the effects of organic nutrients on plant growth are not as quickly seen as with inorganic fertilizers. Thus, new materials and new techniques for increasing the efficiency of organic materials are needed.

Introducing exogenous microorganisms into agricultural environments has been applied to accelerate bioremediation and improve agricultural productivity (Paluch et al. 2013). Although less is known about the practical effectiveness and mechanisms of these products, the assessment nutrient availability to crops (Khan et al. 2007), enhance the proliferation of beneficial bacteria (Priyadi et al. 2005, Javaid 2010), and prevent infection by pathogens (Compant et al. 2005). However, additional microorganisms from commercial products have to be incubated formerly and propagated in the lab and further applied to the fields. Their survival rate and their influences 
42 on plant and soil have been viewed skeptically (Watanabe et al. 2000, Chen et al. 2015).

43 In contrast, indigenous microorganisms may be optimally suited for survival and

44 multiplication in significant amounts (Paluch et al. 2013). However, there is less information

45 available on the ways to activate naturally occurring soil microbial populations. The use of CE

46 produced by plant extraction technology may be one method to activate indigenous soil

47 microbial populations. CE derived from endophytes extracted from different plant species such

48 as soybean (Glycine max (L.) Merr.), lucerne (Medicago sativa L.), the brown algae

49 (Ascophyllum nodosum) (Bestfarming systems Co.), and has been widely used recently. A new

50 bio-molecular method for determining the presence of nifH, the gene harboured in endophytic

51 bacteria for nitrogenase reductase from nodulated plant species has been developed

52 (www.amazingcarbon.com)(Gao et al. 2015, Le et al. 2015). This study demonstrates that CE

53 activates indigenous microorganisms in the soil, particularly $\mathrm{N}$-fixing bacteria or archaea that are

54 not able to be cultured in the laboratory. Besides, increasing evidence suggests that is of

55 lavonoids and flavonoids exuded from the root of many legumes can activate rhizobium genes,

56 which helps in the nodulation process (Peters et al. 1986, Brunetti et al. 2013). Combing

57 microbial remediation with legume remediation is expected to be an economically and

58 environmentally appropriate approach for soil amendment.

59 This study was undertaken to verify if: (1) there are positive effects of adding CE on plant

60 and microbial biomass, microbial activity, plant and soil nutrient contents; (2) combining CE and

61 BOM achieve the highest impacts on soil nutrient contents and lucerne growth; (3) CE stimulates

62 the nodulation of legume as effectively as by inoculating rhizobacteria. Results are expected to 
63

64

65

66

67

68

69

reveal the interactive effects of $\mathrm{CE}$ and $\mathrm{BOM}$ application on plant species growth and soil properties, and aid in the selection of optimal fertilization approaches for soil quality improvement. In addition, the experiments will enable exploring the stimulative effect of $\mathrm{CE}$ on activating and enriching indigenous microorganisms from plant rhizosphere.

\section{Materials and methods}

\section{Experimental design}

A greenhouse experiment was conducted in the laboratory of Prataculture Science, Nanjing Agriculture University, from June 2015 to September 2015 as preliminary trial with only visual evaluation of treatment effects. To determine the actual effects of the treatments, the experiment was completely repeated from October 2015 to January 2016, with quantitative data recorded. The experiment was set up with 4 soil amendment treatments and 10 replications each. The 4 treatments included: bio-organic manure $(\mathrm{BOM})$, compost extract $(\mathrm{CE})$, organic manure + compost extract (CEBOM) and the control.

We collected lucerne seed from barren land in Xilinhot $\left(43^{\circ} 38^{\prime} \mathrm{N}, 116^{\circ} 42^{\prime} \mathrm{E}\right)$, Inner Mongolia, China. The seed were sterilized firstly and germinated on $1.5 \%$ water-agar plates and transplanted into pots (height $15 \mathrm{~cm}$, diameter $15 \mathrm{~cm}$ ). Each pot was filled with $1 \mathrm{~kg}$ of soil (dry weight equivalent) and $200 \mathrm{~g}$ double-washed quartz sand. Soil without any heavy metal content was collected from the same study area and the soil had 1-year history for planting legumes. The soil was collected to $15 \mathrm{~cm}$ depth with $5 \mathrm{~cm}$ diameter soil cores and evenly mixed, then applied to each pot. The characteristics of the soil are listed in Table 1. Prior to seedling transplantation, 
BOM was collected and mixed into the top layer of the potting at a rate of $15 \mathrm{~g}$ per pot. It was made of $50 \%$ pig dung compost and $50 \%$ amino acid fertilizer; the pig dung compost made by composting pig dung at 30 to $70^{\circ} \mathrm{C}$ for 25 days, contained $30.1 \%$ organic matter, $3.0 \% \mathrm{~N}, 2.7 \%$ $\mathrm{P}_{2} \mathrm{O}_{5}, 0.9 \% \mathrm{~K}_{2} \mathrm{O}$; the amino acid fertilizer enzymatically hydrolyzed by aerobic microbial fermeantation for 7 days, contained $40.2 \%$ organic matter, $11.1 \%$ amino acids, $3.4 \% \mathrm{~N}, 1.7 \%$ $\mathrm{P}_{2} \mathrm{O}_{5}, 1.1 \% \mathrm{~K}_{2} \mathrm{O}$ (Zhang et al. 2011, Huang et al. 2011). Four of ten strongest seedlings were finally left per pot. CE consisted of a mixture alfalfa meal 15.9\% (weight/weight), barley grain $10.2 \%$, barley straw $6.4 \%$, wheat straw $4.3 \%$, liquidized fish $8.7 \%$, kelp $39.5 \%$, sulphur $0.3 \%$, calcium carbonate $10.2 \%$, and molasse $4.5 \%$. The mixture was fermented at $<50^{\circ} \mathrm{C}$ for 14 days in an incubator, then extracted, filtered, freezed and dried. The final compositions (minimum guaranteed analysis) contained $16.9 \%$ amino acids, $0.5 \%$ soluble potash (weight/weight), $0.06 \%$ calcium, $1.5 \%$ sulphur, $1.2 \%$ nitrogen, $0.3 \%$ phosphorus. $20 \mathrm{ml}$ of CE (Bestfarming Systems Co.) ( $2 \mathrm{ml} /$ pot for each application) diluted with $5 \mathrm{~L}$ of water were sprayed onto the soil at a rate comparable to agricultural practice with $750 \mathrm{ml} /$ hectare. Four weeks later, $\mathrm{CE}$ was applied for a second time (practical dosage at manufacturers' recommendation) and no more after that.

A supplementary experiment on nodulation effects was conducted when seedlings were transplanted into additional pots (same size as above). The seedlings in the pots were inoculated with $6 \mathrm{ml}$ liquid per pot with rhizobium strains (Rhizobium melilotid Dangeard- CX 107) cultured from nodules (provided by Key Laboratory of Agro-Microbial Resource and Application, China Agriculture University).Bacterial suspensions were diluted to an optical density of $0.70(\lambda=600 \mathrm{~nm})$, which was equivalent to a concentration of $3.10^{8}$ bacteria/ml, as 
104

105

106

107

108

109

110

111

112

113

114

115

116

117

118

119

120

121

122

123

124

measured by Bradford method (Bradford 1976) on a yeast-mannitol culture medium (Vincent and Humphrey 1970).

Starting from 10. June 2015, seedlings were grown under glasshouse conditions at 50-70\% relative humidity and a temperature regime of $20-25^{\circ} \mathrm{C}$ during day and night. Pots were watered to maintain soil water content between 20 and $25 \%$. Eighty days later, seedlings of both experiments were destructively harvested, and separated into leaves, shoots and roots, their biomass measured, and were examined for nodulation by counting and weighing root nodules (roots were washed to remove adhering soil before checking).

\section{Chemical analyses}

Plant samples

Samples of stem and leaves were milled to $<0.2 \mathrm{~mm}$ and analyzed for total C and N. Plant total P content was determined using a UV/visible spectrophotometer (Beckman Coulter DU 800, USA). Plant total $\mathrm{K}$ content was measured using $\mathrm{H}_{2} \mathrm{SO}_{4}$-salicylic acid $-\mathrm{H}_{2} \mathrm{O}_{2}$-Se digestion (Zheng et al. 2012).

Plant samples were ground to pass a $1 \mathrm{~mm}$ sieve and scanned twice using Near-InfraredSpectroscopy (NIRS) technique for forage nutritive value determination (Ren et al. 2016). Nutritional value was tested by evaluating crude protein $(\mathrm{CP}$; nitrogen concentration $\times 6.25)$, neutral detergent fibre (NDF), cellulose digestible organic matter (CDOM) and metabolisable energy (ME) (MJ/kg DM) (Schonbach et al. 2009). NDF was analyzed sequentially using the method described by Vansoest et al. (1991), which used semiautomatic ANKOM 220 technology and was expressed with residual ash. CDOM value as a percentage of organic matter and ME 
125 value were calculated using crude ash (CA) and non-soluble enzymatic substance (EULOS).

126 Detailed calculations are given in equations 1 and 2 below (Schonbach et al. 2009):

$127 \quad \mathrm{CDOM}=100\left(940-\mathrm{CA}-0.62\right.$ EULOS $\left.-0.000221 \mathrm{EULOS}^{2}\right) /(1000-\mathrm{CA}) ;$

128

$$
\mathrm{ME}=13.98-0.0147 \mathrm{CA}-0.0102 \mathrm{EULOS}-0.00000254 \mathrm{EULOS}^{2}+0.00234 \mathrm{CP}
$$

129 Soil samples

130 Soil samples were separated in two portions, one portion was weighed to determine soil bulk density by using a foil sampler $\left(\right.$ volume $\left.=100 \mathrm{~cm}^{3}\right)$ and dried at $105^{\circ} \mathrm{C}$ for $24 \mathrm{~h}$ to calculate water holding capacity $(\%)$, while another portion was stored at $-22^{\circ} \mathrm{C}$ for microbial abundance analysis by real-time PCR (Gupta et al. 2017). Subsamples were sieved to $0.15 \mathrm{~mm}$ and analyzed for soil organic matter $(\mathrm{OM})$, alkaline hydrolysable nitrogen $(\mathrm{N})$, available phosphorus $(\mathrm{P})$, available potassium $(\mathrm{K})$, and total $\mathrm{C}, \mathrm{N}, \mathrm{P}$ and $\mathrm{K}$ content. Soil $\mathrm{OM}$ content was determined through the potassium dichromate external heating method (Sparks et al. 1996). The alkaline-hydrolysable diffusion method was applied to determine alkaline- hydrolysable $\mathrm{N}$ content (Bremner et al. 1996). Available $\mathrm{P}$ was measured using a spectrophotometer, with ammonium molybdate and ascorbic acid as colour reagents (Carter and Gregorich 2008). Available K was measured by ammonium nitrate extraction-the flame photometry method (Sparks et al. 1996). The organic C content was analyzed using $\mathrm{K}_{2} \mathrm{Cr}_{2} \mathrm{O}_{7}-\mathrm{H}_{2} \mathrm{SO}_{4}$ oxidation method. Soil total $\mathrm{N}$ was analyzed with a

Kjeltec analyzer (Kjeltec Analyzer Unit 2300, FOSS, Hillerød, Sweden). Soil total P and K was measured in the same way as plant total P. Soil pH was measured in a 1:2.5 (soil: water) suspension.

Microbial biomass carbon (MBC) and microbial biomass nitrogen $(\mathrm{MBN})$ as well as 
146 microbial respiration (MR) were measured to assess differences in microbial colonization and

147 activity. MBC and MBN were estimated using the chloroform fumigation extraction method

148 (Frostegard et al. 2011). MR was measured in pre-incubated ( $24 \mathrm{~h}$ at $\left.28^{\circ} \mathrm{C}\right)$ samples by

149 determining $\mathrm{CO}_{2}$ evolution over a period of $72 \mathrm{~h}$ (FAL, 1996). The abundance of viable bacteria

150 and fungi as measured according to real-time quantitative PCR-DGGE (denaturing gradient gel

151 electrophoresis) of 16S rDNA, which was performed using the ABI 7300 real-time PCR system

152 (Applied Biosystems, Foster, California, USA) with fluorescence TaqMan ${ }^{\circledR}$ probe detection (Le

153 et al. 2015, Gupta et al. 2017).

154 Statistical analysis

155 One-way ANOVA (analysis of variance) was used to determine differences among 156 treatments for lucerne species growth and soil properties. The LSD-test procedure was used for 157 testing mean differences among control, BOM and CE treatments. The level of significance was $\mathrm{P}<0.05$. All the variables were statistically tested for homogeneity of variance. All statistical analyses were carried out using SAS, Version 9.2 (SAS Institute Inc., Cary, NC, USA).

160

161

162

163

164 165

\section{Results}

3.1. Biomass and nutritional value of lucerne

Shoot, root and total biomass of inoculated lucerne significantly increased $(P<0.05)$ under CE application by $73.3 \%, 38.3 \%$ and $63.8 \%$, respectively (Fig. 1). Compared with the control, the three biomasses of lucerne did not change under CEBOM treatment, and decreased by $17.5 \%$ to $26.6 \%$ when BOM was added. For non-inoculated lucerne, all three biomasses showed highest values with $\mathrm{CE}$ addition alone by increasing from $46.0 \%$ to $85.3 \%$, then were second with 
167 CEBOM treatment. BOM addition did not affect the biomass of non-inoculated lucerne. The 168 effects of amendment treatments on soil characteristics and plant nutritional values were further 169 analyzed by ANOVA (Table S1). CE and BOM significantly affected the nutritional values 170 (Table 2). The CP concentration of lucerne was significantly higher in BOM and CE treatments 171 than in the control. CDBOM and ME showed the same trend in response to treatments. CE and 172 BOM significantly decreased lucerne NDF from 66.18 to $52.45 \mathrm{~g} \mathrm{~kg}^{-1} \mathrm{DM}$ and CE alone 173 decreased NDF by $36.3 \%$.

174 3.2. N, P, K contents in stems, leaves and soil

The $\mathrm{N}$ content of stems, leaves and soil decreased significantly in the order $\mathrm{CEBOM}>\mathrm{BOM}>$

$\mathrm{CE}>$ control (Table 3, Table S1). The $\mathrm{N}$ contents of stem, leaves and soil in the CEBOM treatment were $40.4 \%, 35.0 \%$ and $91.4 \%$ higher than in the control treatment, respectively. The $\mathrm{P}$ content of stems was significantly higher in the three soil amendment treatments than in the control treatment. The $\mathrm{P}$ content of leaves and soils increased in the order: $\mathrm{CEBOM}>\mathrm{CE}>$ $\mathrm{BOM}>$ control. The $\mathrm{K}$ content of stems and soil was significantly higher in the CEBOM treatment than in the other treatments, and both $\mathrm{CE}$ and $\mathrm{BOM}$ treatments had a higher $\mathrm{K}$ content in stems than the control treatment. Soil amendment treatments enhanced the $\mathrm{K}$ content of leaves in comparison with the control treatment. The $\mathrm{K}$ content of soil decreased in the order CEBOM $>$

$\mathrm{CE}>\mathrm{BOM}>$ control treatment.

3.3. Biotic and abiotic characteristics of soils 
188 189 190

MBC was not significantly different between $\mathrm{CE}$ and BOM treatments. Microbial respiration rates and metabolic quotients significantly increased in the order $\mathrm{CEBOM}>\mathrm{BOM}=\mathrm{CE}>$ control. Numbers of soil bacteria and fungi showed an increase in treatments with CE, BOM and CEBOM application, but were higher with CE alone than with BOM. The application of CE and BOM together strongly increased the amounts of bacteria in the rhizosphere soil of lucerne.

Of the three soil amendments, only CEBOM significantly increased soil $\mathrm{pH}$ and water holding capacity (Table 5, Table S1). The three amendment treatments significantly reduced bulk density and increased organic matter, soil alkaline-hydrolysable $\mathrm{N}$, available $\mathrm{P}$ content and available K.

3.4. Comparison between rhizobium nodulation among soil amendment treatments

The highest number of nodules and total nodule weight occurred in inoculated lucerne with the CE treatment (Fig. 2, Table S1 and S2). The number of nodules and the total nodule weight of the inoculated lucerne showed no significant difference with non-inoculated lucerne under CE application. Under BOM application, the nodulation of lucerne decreased significantly. Table S3 showed the effects of treatments on plant $\mathrm{N}$ and soil $\mathrm{N}$ of inoculated lucerne.

\section{Discussion}

The shoot, root and total biomass and the nutritional value of inoculated and non-inoculated lucerne were significantly increased with the application of CE alone and CE with BOM together. It indicates that $\mathrm{CE}$ acts better than $\mathrm{BOM}$ for improving legume growth, because nitrogenfixation can be suppressed by the addition of external nitrogen (Goergen and Chambers 2009). However, it does not imply that BOM can substitute for CE, because highly synergistic effects 
209

210

211

212

213

214

215

216

217

218

219

220

221

222

223

224

225

226

227

228

229

on plant nutrient and soil properties were observed. Both soil biotic (MBC, MBN, MR) and abiotic (soil water holding capacity, organic matter, alkaline $\mathrm{N}$, available $\mathrm{P}$ and $\mathrm{K}$ ) factors were improved, and thus plant growth was enhanced.

When CE was applied, 164\% higher plant biomass occurred, which could be mainly attributed to the stimulation of beneficial microorganisms (increased numbers of bacteria and fungi, Table 4) by accelerating the decomposition of organic materials and increasing the release of nutrients (Javaid and Bajwa 2011). In contrast, BOM provided additional microorganisms and external nutrients to the soil (Higa 2001). These inoculated microorganisms have to compete with naturally occurring bacteria (Sherr et al. 1992). The interactions of different microorganisms may complement each other and further influence plant growth due to microbial diversity (van der Heijden et al. 2008). By stimulating the proliferation of beneficial bacteria and restraining harmful microorganisms through $\mathrm{CE}$ addition, some essential substances such as nucleic acids, amino acids and bioactive substances (e.g. hormones and enzymes) are synthesized (Javaid and Bajwa 2011). They can accelerate the decomposition of lignin materials in the soil and the mineralization of organic material as well as the control of soil diseases, resulting in a change in soil microbial parameters and physical and chemical soil characteristics as seen in this study (Kim et al. 2004, Javaid and Bajwa 2011). Besides, lucerne has been reported to produce root-derived antimicrobials in dole, terpenoid, benzoxazinone, flavonoid and isoflavonoid, which are used for inhibiting soil-borne pathogenic bacteria (Dixon 2001) and thus enhance the symbiosis between plant and beneficial microorganisms. In soil organic amendment systems, beneficial microbes activated by $\mathrm{CE}$ and added by BOM accelerate the mineralization 
230 of soil organic matter (Javaid 2011), which releases more nutrients for plant uptake (Flores et al. 231 1999).

232 Higher uptake of N, P and K by plant and higher soil content of N, P and K (Table 2) indicate 233 that amendment treatments increased the availability of nutrients in the soil. In this study, the soil 234 had a low $\mathrm{pH}$ value indicating acidic conditions, which resulted in low nutrient availability and 235 low inorganic fertilization efficiency (Chen et al. 2015). The observed increase in soil $\mathrm{pH}$ with applying $\mathrm{CE}$ and $\mathrm{BOM}$ together demonstrated that a combination of soil conditioner and BOM could amend an acidic soil by accelerating the rate of microbial processes and thus releasing nutrients more quickly, as shown by other studies (Hati et al. 2006, Lee et al. 2009). Separately, they had no significant effects. CE includes less nutrient elements but has greater effects on soil and plant nutrient in comparison with BOM.

The identical numbers of nodules as well as nodule weight in inoculated and non-inoculated

lucerne added with $\mathrm{CE}$ indicates the ability of $\mathrm{CE}$ for activating indigenous rhizobia (Le et al. 2015). Mechanisms for the maintenance of root-soil contact have been attributed to root exudation (Le et al. 2015). The plant-soil feedback driven by root exudates could initiate and manipulate a signal exchange between roots and soil organisms (Keymer and Lankau 2017). CE may stimulate root exudates, which could initiate one-way signals informing roots on chemical and physical soil properties, and regulating the symbiotic and protective interactions with microbes (Jones et al. 2003, Johnson et al. 2015). The exudates accumulate mainly inducible antimicrobial compounds gathered in the roots (Flores et al. 1999, Dixon 2001). Many 
251 therefore, a number of antimicrobial root exudates are secreted. Le et al. (2015) confirmed that

252 some endophytic actinobacteria had the potential to enhance the growth of lucerne and its

253 interactions in rhizobial symbiosis. The mechanism by which CE produces a stimulatory effect

254 on properties soil and plant growth needs to be further explored.

\section{Conclusions}

256 This study demonstrated that CE application alone and in combination with BOM enhanced

257 lucerne biomass and nutritional value by improving nodulation and soil biotic and abiotic

properties. The similar effects of $\mathrm{CE}$ and $\mathrm{BOM}$ on plants and soils does not necessary mean that

they can be treated as substitutes for one another. Rather, their combination provides a mode of soil amendment which improves soil quality more efficiently. CE synthesizes some kinds of active substrates that stimulate the activity of indigenous rhizobia in the soil rather than adding extra microorganisms into the soil as BOM does. Root exudation may help in regulating soil properties and root-microbe-soil interactions. However, the nature of their reactions in the soil need to be further explored.

265

266

267

268

269

270

271

272

\section{Acknowledgements}

We acknowledge all students for helping sampling measurement. We acknowledge Nanjing Agriculture University for providing lab facilities.

\section{References}

Blakemore, C., A. Fiorentini, and L. Maffei. 1972. A second neural mechanism of binocular depth discrimination. Journal of Physiology 226:725-749.

Bradford, M. M. 1976. A rapid and sensitive method for the quantitation of microgram quantities 
of protein utilizing the principle of protein-dye binding. Analytical Biochemistry 72:248254.

Bremner, J. B., R. J. Smith, and G. J. Tarrant. 1996. A Meisenheimer rearrangement approach to bridgehead hydroxylated tropane alkaloid derivatives. Tetrahedron Letters 37:97-100.

Brunetti, C., M. Di Ferdinando, A. Fini, S. Pollastri, and M. Tattini. 2013. Flavonoids as antioxidants and developmental regulators: relative significance in plants and humans. International Journal of Molecular Sciences 14:3540-3555.

Carter, M. R., and Gregorich, E. G. 2008. Soil sampling and methods of analysis 2nd edition. CRC Press

Chen, D., Y. Wang, Z. Lan, J. Li, W. Xing, S. Hu, and Y. Bai. 2015. Biotic community shifts explain the contrasting responses of microbial and root respiration to experimental soil acidification. Soil Biology and Biochemistry 90:139-147.

Compant, S., B. Duffy, J. Nowak, C. Clement, and E. A. Barka. 2005. Use of plant growthpromoting bacteria for biocontrol of plant diseases: principles, mechanisms of action, and future prospects. Applied and Environmental Microbiology 71:4951-4959.

Dixon, R. A. 2001. Natural products and plant disease resistance. Nature 411:843-847.

Flores, H. E., J. M. Vivanco, and V. M. Loyola-Vargas. 1999. 'Radicle' biochemistry: the biology of root-specific metabolism. Trends in Plant Science 4:220-226.

Frostegard, A., A. Tunlid, and E. Baath. 2011. Use and misuse of PLFA measurements in soils. Soil Biology and Biochemistry 43:1621-1625.

Gao, J., F. Lv, X. Wang, T. Qiu, M. Yuan, J. Li, Y. Zhou, and J. Sun. 2015. Paenibacillus wenxiniae sp nov., a nifH gene -harbouring endophytic bacterium isolated from maize Antonie Van Leeuwenhoek International Journal of General and Molecular Microbiology 108:1015-1022.

Goergen, E.M. and Chambers, J.C. 2009. Influence of a native legume on soil N and plant response following prescribed fire in sagebrush steppe. International Journal of Wildland Fire 18: 665-675.

Gupta, A., A. Dutta, J. Sarkar, D. Paul, M. K. Panigrahi, and P. Sar. 2017. Metagenomic exploration of microbial community in mine tailings of Malanjkhand copper project, India. Genomics Data 12:11-13.

Hati, K. M., K. G. Mandal, A. K. Misra, P. K. Ghosh, and K. K. Bandyopadhyay. 2006. Effect of inorganic fertilizer and farmyard manure on soil physical properties, root distribution, and water-use efficiency of soybean in Vertisols of central India. Bioresource Technology 97:2182-2188.

Henwood, W. D. 2010. Toward a strategy for the conservation and protection of the world's temperate grasslands. Great Plains Research 20:121-134.

Higa, T. 2001. Effective microorganisms in the context of Kyusei Nature Farming: a technology for the future. In: Proceedings of the conference on greater productivity and a cleaner environment through Kyusei Nature Farming, University of Pretoria, Pretoria, South Africa, 28-31 October, 1999, pp. 40-43.

Huang, X. Q., Chen, L. H., Ran, W., Shen, Q. R., and Yang, X. M. 2011. Trichoderma 
harzianum strain SQR-T37 and its bio-organic fertilizer could control Rhizoctonia solani damping-off disease in cucumber seedlings mainly by the mycoparasitism. Appl Microbiol Biotechnol 91:741-755

Hu, C. and Y. Qi. 2013. Long-term effective microorganisms application promote growth and increase yields and nutrition of wheat in China. European Journal of Agronomy 46:63-67.

Javaid, A. 2010. Beneficial microorganisms for sustainable agriculture. In: Lichtfouse E. (ed) Genetic Engineering, Biofertilisation, Soil Quality and Organic Farming. Springer, Dordrecht, pp. 347-369.

Javaid, A. 2011. Effects of biofertilizers combined with different soil amendments on potted rice plants. Chilean Journal of Agricultural Research 71:157-163.

Javaid, A. and R. Bajwa. 2011. Field evaluation of effective microorganisms (EM) application for growth, nodulation, and nutrition of mung bean. Turkish Journal of Agriculture and Forestry 35:443-452.

Johnson, N. C., G. W. T. Wilson, J. A. Wilson, R. M. Miller, and M. A. Bowker. 2015. Mycorrhizal phenotypes and the Law of the Minimum. New Phytologist 205:1473-1484.

Jones, D. L., J. Farrar, and K. E. Giller. 2003. Associative nitrogen fixation and root exudation : what is theoretically possible in the rhizosphere? Symbiosis 35:19-38.

Keymer, D. P. and R. A. Lankau. 2017. Disruption of plant-soil-microbial relationships influences plant growth. Journal of Ecology 105:816-827.

Khan, M. S., A. Zaidi, and P. A. Wani. 2007. Role of phosphate-solubilizing microorganisms in sustainable agriculture - a review. Agronomy for Sustainable Development 27:29-43.

Kim, M. K., K. M. Choi, C. R. Yin, K. Y. Lee, W. T. Im, J. H. Lim, and S. T. Lee. 2004. Odorous swine wastewater treatment by purple non-sulfur bacteria, Rhodopseudomonas palustris, isolated from eutrophicated ponds. Biotechnology Letters 26:819-822.

Le, X. H., C. M. M. Franco, R. A. Ballard, and E. A. Drew. 2015. Isolation and characterisation of endophytic actinobacteria and their effect on the early growth and nodulation of lucerne (Medicago sativa L.). Plant and Soil 40:1-12.

Lee, S. B., C. H. Lee, K. Y. Jung, K. Do Park, D. Lee, and P. J. Kim. 2009. Changes of soil organic carbon and its fractions in relation to soil physical properties in a long-term fertilized paddy. Soil and Tillage Research 104:227-232.

Paluch, E. C., M. A. Thomsen, and T. J. Volk. 2013. Effects of resident soil fungi and land use history outweigh those of commercial mycorrhizal inocula: testing a restoration strategy in unsterilized soil. Restoration Ecology 21:380-389.

Peters, N. K., J. W. Frost, and S. R. Long. 1986. A plant flavone, luteolin, induces expression of rhizobium-meliloti nodulation genes. Science 233:977-980.

Priyadi, K., A. Hadi, T. H. Siagian, C. Nisa, A. Azizah, N. Raihani, and K. Inubushi. 2005. Effect of soil type, applications of chicken manure and effective microorganisms on corn yield and microbial properties of acidic wetland soils in Indonesia. Soil Science and Plant Nutrition 51:689-691.

Ren, H., G. Han, P. Schoenbach, M. Gierus, and F. Taube. 2016. Forage nutritional characteristics and yield dynamics in a grazed semiarid steppe ecosystem of Inner 
355

356

357

358

359

360

361

362

363

364

365

366

367

368

369

370

371

372

373

374

375

376

377

378

379

380

381

382

383

384

385

Mongolia, China. Ecological Indicators 60:460-469.

Schonbach, P., H. Wan, A. Schiborra, M. Gierus, Y. Bai, K. Muller, T. Glindemann, C. Wang, A. Susenbeth, and F. Taube. 2009. Short-term management and stocking rate effects of grazing sheep on herbage quality and productivity of Inner Mongolia steppe. Crop and Pasture Science 60:963-974.

Sherr, B. F., E. B. Sherr, and J. McDaniel. 1992. Effect of protistan grazing on the frequency of dividing cells in bacterioplankton assemblages. Applied and Environmental Microbiology 58:2381-2385.

Soumare, M., F. M. G. Tack, and M. G. Verloo. 2003. Effects of a municipal solid waste compost and mineral fertilization on plant growth in two tropical agricultural soils of Mali. Bioresource Technology 86:15-20.

Sparks, D. L., Page, A. L., Helmke, P. A., Loeppert, R. H., and Soltanpour, P. N. 1996. Methods of soil analysis Part 3: Chemical methods. Madison, WI, USA: Soil Science Society of America, Inc. and American Society of Agronomy, Inc.

van der Heijden, M. G. A., R. D. Bardgett, and N. M. van Straalen. 2008. The unseen majority: soil microbes as drivers of plant diversity and productivity in terrestrial ecosystems. Ecology Letters 11:296-310.

Vansoest, P. J., J. B. Robertson, and B. A. Lewis. 1991. Methods for dietary fiber, neutral detergent fiber, and nonstarch polysaccharides in relation to animal nutrition. Journal of Dairy Science 74:3583-3597.

Vincent, J. M. and B. Humphrey. 1970. Taxonomically significant group antigens in Rhizobium. Journal of General Microbiology 63:379-382.

Watanabe, K., M. Miyashita, and S. Harayama. 2000. Starvation improves survival of bacteria introduced into activated sludge. Applied and Environmental Microbiology 66:39053910.

Zhang, N., Wu, K., He, X., Li, S. Q., Zhang, Z. H., Shen, B., Yang, X. M., Zhang, R. F., Huang, Q. W., and Shen, Q. R. 2011. A new bioorganic fertilizer can effectively control banana wilt by strong colonization with Bacillus subtilis N11. Plant and Soil 344:87-97.

Zheng, S., H. Ren, W. Li, and Z. Lan. 2012. Scale-dependent effects of grazing on plant C: N: P stoichiometry and linkages to ecosystem functioning in the Inner Mongolia grassland. PLoS ONE 7:e51750. 
386 Table 1 Soil properties in the study area

\begin{tabular}{|c|c|c|c|c|c|c|c|c|}
\hline $\begin{array}{l}\text { Soil } \\
\text { property }\end{array}$ & $\mathrm{pH}$ & $\begin{array}{l}\text { Bulk density } \\
\left(\mathrm{g} / \mathrm{cm}^{3}\right)\end{array}$ & $\begin{array}{l}\text { WHC } \\
(\%)\end{array}$ & $\begin{array}{l}\mathrm{OM} \\
(\mathrm{g} / \mathrm{kg})\end{array}$ & $\begin{array}{l}\text { Organic C } \\
(\%)\end{array}$ & $\begin{array}{l}\text { Total N } \\
(\%)\end{array}$ & $\begin{array}{l}\text { Total } \\
(\%)\end{array}$ & $\begin{array}{c}\text { P C: } \mathrm{N} \text { ratio } \\
(\%)\end{array}$ \\
\hline value & 5.88 & 1.61 & 25.73 & 13.25 & 12.12 & 0.83 & 0.16 & 14.60 \\
\hline
\end{tabular}

387 Abbreviations are: OM (organic matter), WHC (water holding capacity).

Table 2 Effect of compost extract (CE), bio-organic manure (BOM) and CE + BOM (CEBOM) application on shoot nutrient values of lucerne

\begin{tabular}{lllll}
\hline Treatment & CP & NDF & CDOM & ME \\
& $(\mathrm{g} \mathrm{DM} / \mathrm{kg})$ & $(\mathrm{g} \mathrm{DM} / \mathrm{kg})$ & $(\mathrm{g} \mathrm{DM} / \mathrm{kg})$ & $(\mathrm{MJ} \mathrm{DM} / \mathrm{kg})$ \\
\hline Control & $17.7 \mathrm{c}$ & $66.18 \mathrm{a}$ & $68.61 \mathrm{~b}$ & $9.84 \mathrm{~b}$ \\
$\mathrm{CE}$ & $23.3 \mathrm{a}$ & $58.24 \mathrm{c}$ & $77.77 \mathrm{a}$ & $10.87 \mathrm{ab}$ \\
BOM & $21.4 \mathrm{~b}$ & $61.48 \mathrm{ab}$ & $72.42 \mathrm{~b}$ & $10.09 \mathrm{~b}$ \\
CEBOM & $24.6 \mathrm{a}$ & $52.45 \mathrm{bc}$ & $79.99 \mathrm{a}$ & $11.01 \mathrm{a}$ \\
\hline
\end{tabular}

Abbreviations are: DM - dry matter; CP - crude protein; NDF - neutral detergent fibre; CDOM -

cellulose digestible organic matter; ME - metabolisable energy; and MJ - joules per mole

Different letters within a column indicate significant differences $(P<0.05)$ between treatments.

LSD multiple comparisons were used. 
Table 3 Effects of compost extract (CE), bio-organic manure (BOM) and CE + BOM (CEBOM)

400 application on N, P, K contents of lucerne stems, leaves and soil

\begin{tabular}{|c|c|c|c|c|c|c|c|c|c|}
\hline \multirow[t]{2}{*}{ Treatment } & \multicolumn{3}{|c|}{ Stem $(\mathrm{g} / \mathrm{kg})$} & \multicolumn{3}{|c|}{ Leaf $(\mathrm{g} / \mathrm{kg})$} & \multicolumn{3}{|c|}{ Soil (g/kg) } \\
\hline & $\mathrm{N}$ & $\mathrm{P}$ & $\mathrm{K}$ & $\mathrm{N}$ & $\mathrm{P}$ & $\mathrm{K}$ & $\mathrm{N}$ & $\mathrm{P}$ & $\mathrm{K}$ \\
\hline Control & $2.30 \mathrm{c}$ & $0.72 b$ & $11.90 \mathrm{c}$ & $3.77 \mathrm{c}$ & $1.30 \mathrm{c}$ & $7.51 \mathrm{~b}$ & $0.81 \mathrm{c}$ & $0.18 \mathrm{c}$ & $1.31 \mathrm{c}$ \\
\hline $\mathrm{CE}$ & $2.73 b$ & $1.17 \mathrm{a}$ & $24.66 b$ & $4.89 b$ & $2.13 b$ & $13.39 \mathrm{a}$ & $1.29 b$ & $0.26 \mathrm{~b}$ & $2.46 \mathrm{~b}$ \\
\hline BOM & $2.98 b$ & $1.17 \mathrm{a}$ & $24.28 b$ & $4.19 b$ & $2.02 b$ & $13.36 \mathrm{a}$ & $1.20 \mathrm{~b}$ & $0.24 b$ & $2.00 \mathrm{~b}$ \\
\hline CEBOM & $3.23 \mathrm{a}$ & $1.22 \mathrm{a}$ & $30.35 a$ & $5.09 a$ & $2.37 \mathrm{a}$ & $13.17 \mathrm{a}$ & $1.55 \mathrm{a}$ & $0.35 \mathrm{a}$ & $3.54 \mathrm{a}$ \\
\hline
\end{tabular}

401

Different letters within a column indicate significant differences $(P<0.05)$ between treatments.

402 LSD multiple comparisons were used.

403

404 Table 4 Effects of compost extract (CE), bio-organic manure (BOM) and CE + BOM (CEBOM) application on $\mathrm{MBC}, \mathrm{MBN}, \mathrm{MR}, \mathrm{QCO}_{2}$ and numbers of bacteria and fungi in the rhizosphere soil 406 of lucerne

\begin{tabular}{|c|c|c|c|c|c|c|}
\hline Treatment & $\begin{array}{l}\mathrm{MBC} \\
(\mathrm{mg} / \mathrm{kg})\end{array}$ & $\begin{array}{l}\mathrm{MBN} \\
(\mathrm{mg} / \mathrm{kg})\end{array}$ & $\begin{array}{l}\text { MR } \\
(\mathrm{mg} / \mathrm{kg} / \mathrm{d})\end{array}$ & $\begin{array}{l}\mathrm{QCO}_{2} \\
(\mathrm{mg} \mathrm{C} / \mathrm{kg})\end{array}$ & $\begin{array}{l}\text { Bacteria } \\
\left(\times 10^{6} \text { copies } / \mathrm{ml}\right)\end{array}$ & $\begin{array}{l}\text { Fungi } \\
\left(\times 10^{6} \text { copies } / \mathrm{ml}\right)\end{array}$ \\
\hline Control & $303.21 \mathrm{c}$ & $63.86 \mathrm{c}$ & $49.01 \mathrm{c}$ & $13.49 \mathrm{c}$ & $22.5 \mathrm{~d}$ & $3.20 \mathrm{c}$ \\
\hline $\mathrm{CE}$ & $384.44 b$ & $70.60 \mathrm{~b}$ & $57.33 b$ & $14.92 b$ & $34.7 b$ & $4.33 \mathrm{a}$ \\
\hline BOM & $340.73 b$ & $62.80 \mathrm{c}$ & $59.81 \mathrm{~b}$ & $14.36 b c$ & $30.0 \mathrm{c}$ & $4.01 \mathrm{~b}$ \\
\hline CEBOM & $414.50 \mathrm{a}$ & $83.03 \mathrm{a}$ & $89.00 \mathrm{a}$ & $17.25 \mathrm{a}$ & $38.5 \mathrm{a}$ & $4.35 \mathrm{a}$ \\
\hline
\end{tabular}

408 (microbial respiration rate), $\mathrm{QCO}_{2}$ (metabolic quotient), $\mathrm{N}=20$. 
409 Different letters within a column indicate significant differences $(P<0.05)$ between treatments.

410 LSD multiple comparisons were used.

411 Table 5 Effects of compost extract (CE), bio-organic manure (BOM) and CE + BOM (CEBOM)

412 application on soil characteristics

\begin{tabular}{llllllll}
\hline Treatment & $\mathrm{pH}$ & $\begin{array}{l}\text { Bulk density } \\
\left(\mathrm{g} / \mathrm{cm}^{3}\right)\end{array}$ & $\begin{array}{l}\text { WHC } \\
(\%)\end{array}$ & $\begin{array}{l}\text { OM } \\
(\mathrm{g} / \mathrm{kg})\end{array}$ & $\begin{array}{l}\text { Alkaline N } \\
(\mathrm{mg} / \mathrm{kg})\end{array}$ & $\begin{array}{l}\text { Available P } \\
(\mathrm{mg} / \mathrm{kg})\end{array}$ & $\begin{array}{l}\text { Available K } \\
(\mathrm{mg} / \mathrm{kg})\end{array}$ \\
\hline Control & $5.90 \mathrm{~b}$ & $1.63 \mathrm{a}$ & $25.38 \mathrm{bc}$ & $14.22 \mathrm{~b}$ & $67.60 \mathrm{c}$ & $4.02 \mathrm{c}$ & $79.88 \mathrm{c}$ \\
$\mathrm{CE}$ & $6.05 \mathrm{ab}$ & $1.47 \mathrm{~b}$ & $28.48 \mathrm{~b}$ & $23.03 \mathrm{a}$ & $102.46 \mathrm{~b}$ & $35.85 \mathrm{~b}$ & $159.79 \mathrm{~b}$ \\
$\mathrm{BOM}$ & $5.95 \mathrm{~b}$ & $1.46 \mathrm{~b}$ & $25.87 \mathrm{c}$ & $22.53 \mathrm{a}$ & $110.63 \mathrm{~b}$ & $50.08 \mathrm{a}$ & $204.70 \mathrm{a}$ \\
CEBOM & $6.33 \mathrm{a}$ & $1.32 \mathrm{~b}$ & $35.17 \mathrm{a}$ & $25.37 \mathrm{a}$ & $128.20 \mathrm{a}$ & $52.83 \mathrm{a}$ & $214.37 \mathrm{a}$ \\
\hline
\end{tabular}

413 Abbreviations are: OM (organic matter), WHC (water holding capacity)

414 Different letters within a column indicate significant differences $(P<0.05)$ between treatments.

415 LSD multiple comparisons were used.

416

417

418

419

420

421

422

423

424 
Fig. 1 Shoot biomass, root biomass and total biomass of inoculated (a) and non-inoculated (b) lucerne under different soil amendment treatments: control, compost extract (CE), bio-organic manure $(\mathrm{BOM})$ and compost extract + bio-organic manure (CEBOM). Bars represent the standard errors, $\mathrm{n}=20$

Fig. 2 Effects of soil amendment treatments: control, compost extract (CE), bio-organic manure 433 (BOM) and compost extract + bio-organic manure (CEBOM) on inoculated and non-inoculated 434 nodulation of lucerne plants. (a): number of nodules; (b): total nodule weight. Straight line 435 showed the same level between inoculated control and non-inoculated CE adding treatment. Bars 436 represent standard errors, $\mathrm{n}=20$

437

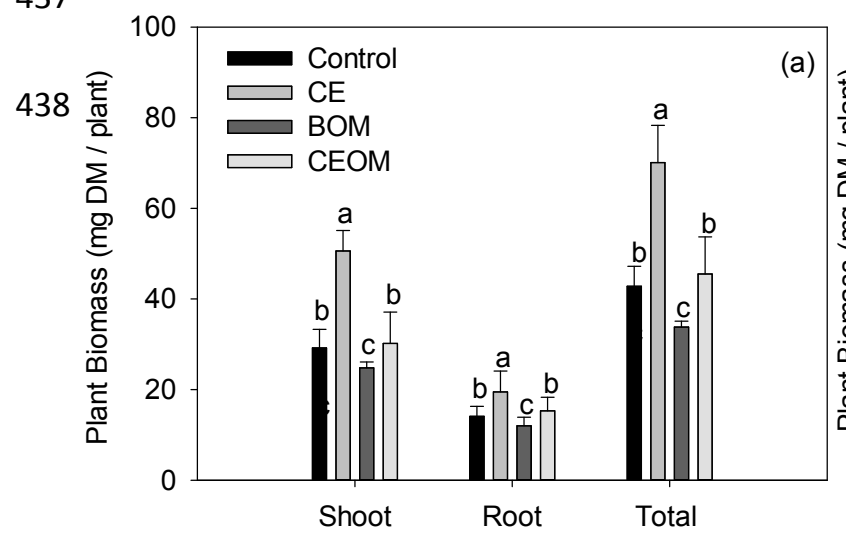

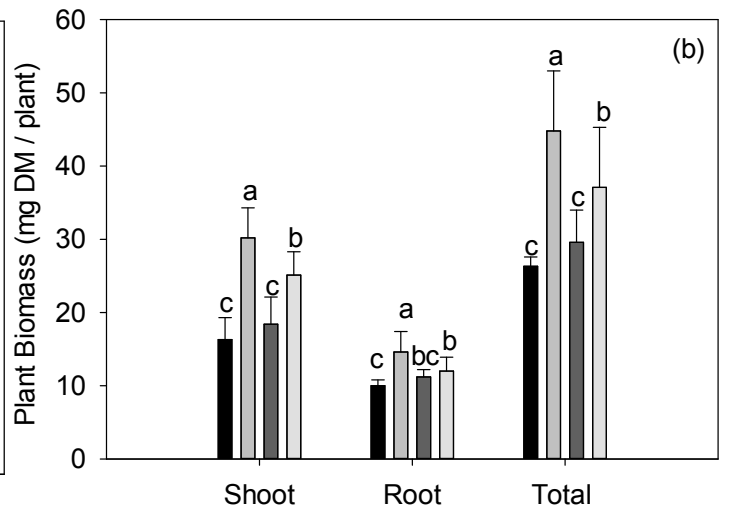

Fig. 1

Fig. 2 

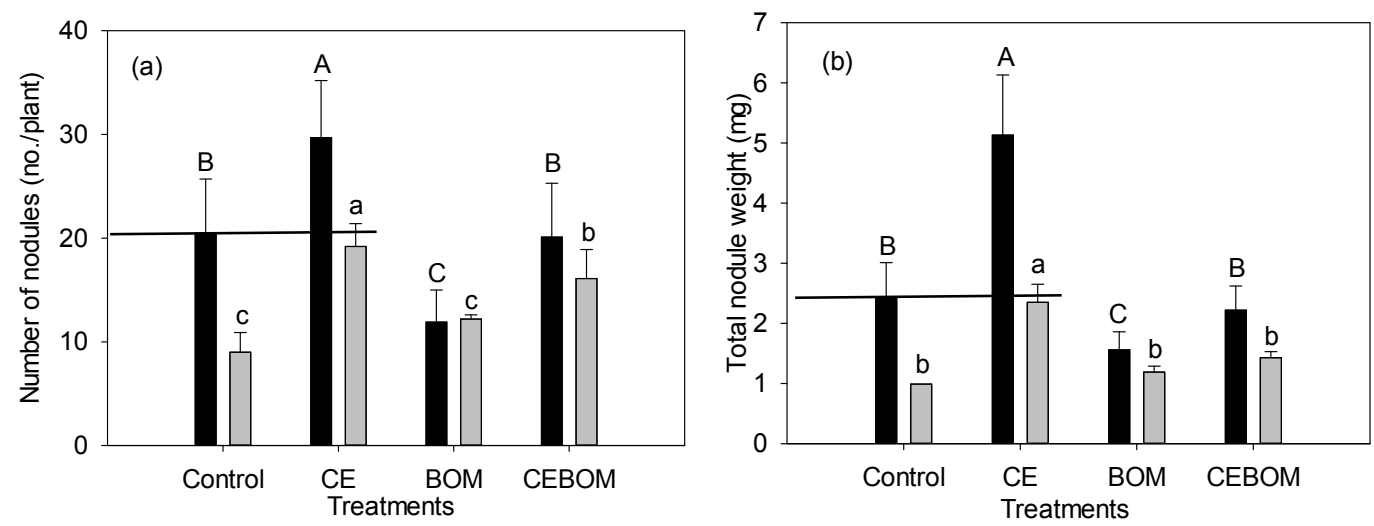